\title{
FACTORS AFFECTING BIOLEACHING IN THE PROCESSING OF NON-METALLICS
}

\author{
IVETA ŠTYRIAKOVÁ \\ Department of Biotechnology, Institute of Geotechnics of the Slovak Academy of \\ Sciences, Watsonova 45, Košice, SK-043 53, Slovak Republic (bacil@saske.sk)
}

\begin{abstract}
Biotechnological treatment of non-metallics is based on bacterial leaching of raw material and dissolution of Fe. Bacterial iron dissolution ability is dependent on various physicochemical factors as temperature, acidity of solutions, redox potential, rapidity of water circulation and presence of organic sources.

The Fe content in the quartz sands and feldspar samples by the biological leaching decreased as much as $60 \%$ and by subsequent using of electromagnetic separation of feldspars, the decrease of Fe content in $74 \%$ was achieved. However, the application of magnetic separation of quartz sands after bioleaching resulted in total iron removal of $93 \%$ and in such combined way prepared product contained $0.024 \%$ of $\mathrm{Fe}_{2} \mathrm{O}_{3}$.

Achieved results on iron removal point to the fact that combination of leaching and magnetic separation enables to obtain product usable in glass and ceramic industry.
\end{abstract}

Key words: bioleaching, non-metallics, iron, Bacillus sp.

\section{Introduction}

Non-metallic raw materials such as silicates, carbonates and oxides contain no energy source for the microorganisms to utilize. Such materials may be leached by using heterotrophic bacteria and fungi, which require an organic carbon source as a source of energy and carbon for their growth. Bioleaching of non-metallic minerals may be used for the recovery of metals from low-grade ores and minerals as well as for the beneficiation of mineral raw materials, recovery of metals from sediments, and heavy metal detoxification of soils and solid residues (JAIN, 2004).

Heterotrophic bacteria and fungi have the potential for producing acidic metabolites that are able to solubilize oxide, silicate, carbonate and hydroxide minerals by reduction, acidolysis and complexation mechanisms (JAIN, 2004).

The use of fungi presents a problem, however. The material to be leached is often adsorbed to or enclosed by the fungal mycelium. This is especially undesirable in the benefication of coal, bauxite and other materials. In this case the process must either be performed in two separated steps: (1) metabolite production and (2) leaching by the metabolite (GROUDEV and GROUDEVA, 1986; VACHON et al., 1994; BRAND et al., 1999)

Bioleaching processes using heterotrophic bacteria have received little attention although heterotrophs in the genera Bacillus and Pseudomonas have been found effective in the bioleaching of non-sulfidic minerals (KARAVAIKO et al., 1980). Naturally occurring silicates contain oxidic iron minerals as coatings on grains or impregnations in the matrix. The extent of iron removal from industrial silicate minerals depends on the mineralogy and distribution of iron in silicate rocks. For this reason, bioleaching studies with industrial minerals for their beneficiation have 
examined the kinetics of iron dissolution from the siliceous matrix (VEGLIO, 1997). In the present works, iron reduction was monitored as a measure of bacterial activity in the bioleaching of non-metallic raw materials. The aim of this was to remit on bacterial kind of Bacillus spp. can be used for bioleaching and the effect of factors on the extent of $\mathrm{Fe}$ removal from non-metallics.

\section{Materials and methods}

The iron - bearing minerals (goethite, mica, smectite) decrease the quality of nonmetallic material. Bioleaching medium containing $\mathrm{NaH}_{2} \mathrm{PO}_{4}-0.5 \mathrm{~g} / \mathrm{l}, \mathrm{MgSO}_{4} \cdot 7 \mathrm{H}_{2} \mathrm{O}-$ $0.5 \mathrm{~g} / 1, \quad\left(\mathrm{NH}_{4}\right)_{2} \mathrm{SO}_{4}-1.0 \mathrm{~g} / 1, \mathrm{NaCl}-0.2 \mathrm{~g} / \mathrm{l}$. However, medium was changed six times during bioleaching at 17 days intervals under aseptic conditions. The carbon sources were glucose, sucrose, galactose, technical-grade sucrose and molasses (all at $20 \mathrm{~g} / \mathrm{l}$ ).

The samples were inoculated with a mixture of both Bacillus cereus, Bacillus mycoides and Bacillus pumilus strains. The flasks were incubated statically for 3 or 4 months at $28^{\circ} \mathrm{C}$. The abiotic controls were cultivated under the same conditions. After incubation, the culture solutions were separated from the biomass by means of membrane filtration.

Quantitative changes in the solid phase were measured with a Model 30 Varian atomic absorption spectrometer (Varian, Inc., Melbourne, Vic., Australia). Dissolved $\mathrm{Fe}^{2+}$ and $\mathrm{Fe}^{3+}$ were measured spectrophotometrically using the phenantroline method (HERRERA et al., 1989; STUCKY and ANDERSON, 1981).

Headspace gas was analyzed for $\mathrm{CO}_{2}$ concentration using a gas chromatograph Chrom 5 (L.P. Praha, Prague, Czech Republic) equipped with a TC detector.

Bacterial oxidation of sucrose and glucose was analyzed as described by DUBOIS et al. (1956).

Morphological and chemical changes in the surfaces of individual mineral grains were investigated by scanning electron microscopy (SEM) and energy-dispersion microanalysis (EDS), respectively. Mineral samples were coated with carbon and examined under a TESLA BS 340 (TESLA Elmi, Brno, Czech Republic) scanning electron microscope.

Solid residues were analyzed by X-ray diffraction using a Philips X'Pert SW-binary diffractometer with $\mathrm{CuK} \alpha$ radiation $(40 \mathrm{kV}, 50 \mathrm{~mA})$, equipped with an automatic divergence slit, sample spinner, and a graphite secondary monochromator. Data were collected for $2-60^{\circ} 2 \Theta$ with a step width of $0.05^{\circ}$ and a counting time of $30 \mathrm{sec}$ per $0.05^{\circ}$.

Dry electromagnetic separation was carried out using a laboratory high gradient magnetic separator with the induction of magnetic field at $1.3 \mathrm{~T}$.

\section{Results and discussion}

The iron-bearing minerals can be easily removed by magnetic separation, and ultra-fine iron particles are difficult to treat by conventional mineral processing methods, biochemical leaching appears to be the alternative for the effective removal of iron minerals. Biotechnological treatment is based on bacterial leaching of raw 
material and dissolution of $\mathrm{Fe}$. These processes are in last decades often observed in situ at weathering of silicate minerals in soil. In order to optimize a leaching process, it is necessary to understand the nature of the biotic reactions. Factors that influence these reactions include the kind of microbial population as well as the mineralogical properties of the raw materials to be leached and also physicochemical parameters:

\subsection{Microbial population}

Heterotrophic bacteria of Bacillus strains are ubiquitous in non-metallic deposit (ŠTYRIAKOVÁ and ŠTYRIAK, 2002), they are non-pathogenic and are also facultative anaerobic bacteria enabling an easy manipulation during non-metallic treatment, increased rapidly in the numbers of cell during non-metallic treatment and targently produced organic acid in silicate structures.

The leaching effect, observed by measurement of $\mathrm{Fe}^{2+}$ and $\mathrm{Fe}^{3+}$ concentration in solution, showed higher activities bacterial kind of Bacillus spp. isolated from Bajkal Lake and also using of yeast Saccharomyces sp. during bioleaching of quartz sands. However, every kinds of Bacillus spp. isolated from Slovak deposit and from Bajkal Lake were very active in iron reduction and dissolution during bioleaching of feldspar raw material.

The results of experiments confirmed the ability of bacteria of Bacillus genus to corrode silicate minerals in feldspar raw materials and quartz sands with subsequent extraction of intergranularly bound iron and smectite as unrequested admixture in nonmetallic raw materials (ŠTYRIAKOVÁ et al., 2003b, ŠTYRIAKOVÁ et al., 2007a).

\section{2 Mineralogical properties}

The effect of biological leaching is dependent from mineralogical composition of certain raw material and the form of iron binding. Bioleaching was effective for the removal of surface layers comprising fine iron minerals, fine-grained mica and iron smectite fraction from non-metallics. Quartz sands containing mineral impurities in form siderite and mica were successfully treated with bioleaching and elutriation. In the process, poorly crystalline Fe-oxides that sealed siderite nodules were released due to the bacterial action from intergranular space of quartz sands. These Fe-oxides formed a finegrained fraction with Fe-bearing minerals and fine mica fraction which were subsequently removed by elutriation process (ŠTYRIAKOVÁ et al., 2003c). Other quartz sands showed the presence of iron smectite coatings in quartz grains. The bioleaching treatment removed these surface coatings, presumably through the action of organic acid produced by the bacteria, and released fine clay particles from quartz grains. Independent iron minerals were removed by magnetic separation (ŠTYRIAKOVÁ et al., 2007a).

Magnetic separation removed independent particles of iron bearing minerals such as biotite and ilmenite. The extent of iron removal moved approximately $60-74 \%$ in combination of bioleaching and magnetic separation of feldspar treatments (ŠTYRIAKOVÁ et al., 2006). The application of magnetic separation of quartz sands after bioleaching resulted in total iron removal of 93 \% (ŠTYRIAKOVÁ et al., 2007a). 


\subsection{Temperature}

At Slovakia, there is often colder weather. That is why active bacteria with cold shock proteins in their genomes should be suitable for the use at leaching of nonmetallic raw materials under such climatic conditions. In view of the low temperature of water at the bottom of Baikal Lake, it can be assumed that cold-adapted microorganisms are found in the sediments. Psychrophilic and psychrotrophic microorganisms are able to grow at temperatures around $0{ }^{\circ} \mathrm{C}$. Psychrophilic microorganisms have an optimum growth temperature $\leq 15{ }^{\circ} \mathrm{C}$ and do not grow above $20{ }^{\circ} \mathrm{C}$; psychrotrophic (psychrotolerant) microorganisms have their optimum growth above $15{ }^{\circ} \mathrm{C}$ (MARGESIN et al., 2003). Mesophilic bacteria prefer temperatures between 20 and $40{ }^{\circ} \mathrm{C}$, but some mesophiles can slowly grow at low temperatures. Exposure of bacterial cells to a cold shock leads to the synthesis of cold-shock proteins (csp) (FRANCIS et al., 1997). Psychrotrophic and mesophilic strains can be differentiated using PCR by the primers BcFF2, BcAPF1, and BcAPR1 for the amplification of mesophilic/psychrotrophic cspF and psychrotrophic cspA genes (FRANCIS et al., 1998). In the case of mesophilic strains, one 284 bp PCR product was amplified, in the case of psychrotrophic strains, two $160 \mathrm{bp}$ and $284 \mathrm{bp}$ PCR products were obtained. Thus, as a second step for the verification of the quality of DNA isolated, the PCR identification of this cold-shock protein was chosen. From the results it follows that the DNA from psychrotrophic microorganisms was amplified. As the psychrotrophic Bacillus mycoides was isolated from Baikal Lake sediments, the DNAs from psychrotrophic Bacillus cereus CCM145 and mesophilic Bacillus thuringiensis $\mathrm{CCM} 19^{\mathrm{T}}$ were used as the control in PCR, too (ŠPANOVÁ, 2006).

\subsection{Eh and pH of solutions}

Heterotrophic bacteria formed anaerobic conditions by microbial respiration after each replacement of medium after 1 day. The creation of Eh gradually decreased from $-110 \mathrm{mV}$ in solution to $-380 \mathrm{mV}$ in sample bed (ŠTYRIAKOVÁ et al., 2006). The bacteria of Bacillus spp. were inoculated into media with sample at the beginning of each batch test, it was assumed that gases were produced and $\mathrm{pH}$ was lowered from 7 to 4 due to the fermentation of an organic source during 5 days. Cumulative measurement of $\mathrm{CO}_{2}$ was made only for the first four days of incubation in the glucose-sucrose medium. The results showed the formation of $27 \mathrm{mg} \mathrm{CO}_{2}$ from $2 \mathrm{~g}$ sucrose and $4 \mathrm{mg} \mathrm{CO}_{2}$ from $2 \mathrm{~g}$ glucose. These values are extremely low and may reflect a high production of organic acids (ŠTYRIAKOVÁ et al., 2007b).

\subsection{Water circulation}

Experimental studies of the effect of microorganisms on iron removal were performed in either closed (batch) or open (percolated columns) reaction vessels. The availability of carbon source and its concentration in the medium is found to be crucial for the growth of the heterotrophic organisms and metabolite production (CASTRO et 
al., 2000). Our results from chemical analyses of leaches and solid phases showed that iron dissolution from non-metallic raw materials via aqueous - phase transport in the batch experiment was increased by the sufficient consumption of organic source, thereby allowing a higher increase in the extent of Fe removal from natural sample materials. In contrast to the batch bioleaching, a lower Fe dissolution was observed by biological leaching in percolator columns (ŠTYRIAKOVÁ et al., 2006).

\subsection{Organic materials}

The effect of carbon source was tested in media inoculated with B. cereus by the addition of glucose, sucrose, galactose, technical-grade sucrose and molasses. The results showed that the extent of iron dissolution was higher in the presence technicalgrade sucrose and molasses after 6 days of bioleaching of non-metallics. Molasses can be used as a relatively inexpensive organic carbon source for the heterotrophs, leading to the formation of metabolites, most notably organic acids acting as leaching agents (ŠTYRIAKOVÁ et al., 2007b).

\section{Conclusion}

The results were presented in the many publications may serve as a starting point for development of flexible biotechnology for non-metallic's beneficiation, where either bacterial $\mathrm{Fe}^{3+}$ dissolution and $\mathrm{Fe}^{2+}$ reduction would be managed, depending on the many physicochemical factors.

Acknowledgements: This work was supported by the Slovak Science and Technology Assistance Agency (Contract APVT-51-006304) and Slovak Academy of Science (VEGA 2/5033/5).

\section{References}

CASTRO, I.M., FIETTO, J.L.R., VIEIRA, R.X., TROPIA, M.J.M., CAMPOS, L.M.M., PANIAGO, E.B., BRANDAO, R.L.: Bioleaching of zinc and nickel from silicate using Aspergillus niger culture. Hydrometallurgy, 57, 2000, 39-49.

DUBOIS, M., GILlES, K.A., HAMILTON, J.K., REBERS, P.A., SMITH, F.: Colorimetric method for determination of sugars and related substances. Anal. Chem., 28, 1956, 350-356.

FRANCIS, K. P., STEWART, G. S. A. B.: Detection and speciation of bacteria through PCR using universal major cold-shock protein primer oligomers. J. Ind. Microbiol. Biotechnol., 19, 1997, 286-293.

FRANCIS, K. P., MAYER, R., VON STETTEN, F., STEWART, G. S. A. B., SCHERER, S.: Discrimination of psychrotrophic and mesophilic strains of the Bacillus cereus group by PCR targeting of major cold shock protein genes. Appl. Environ. Microbiol., 64, 1998, 3525-3529.

GROUDEV,S.N., GROUDEVA,V.I.: Biological leaching of aluminium from clays. Biotechnol. Bioeng. Symp., 16, 1986, $91-99$. 
HERRERA, L., RUIZ, P., AGUILLON, J.C., FEHRMAN, A.: A new spectrometric method for the determination of ferrous iron in the presence of ferric iron. J. Chem. Technol. Biotechnol., 89, 1989, 171-181.

MARGESIN, R., LABBÉ, D., SCHINNER, F., GREER, C. W., WHYTE, L. G.: Characterization of hydrocarbon-degrading microbial populations in contaminated and pristine Alpine soils. Appl. Environ. Microbiol., 69, 2003, 3085-3092.

STUCKY, J.W., ANDERSON, W.L.: The quantitative assay of minerals for $\mathrm{Fe}^{2+}$ and $\mathrm{Fe}^{3+}$ using 1,10-phenantroline: I. Sources of variability. Soil Sci. Soc. Am. J. 45, 1981, 633-637.

ŠPANOVÁ, A., RITTICH, B., ŠTYRIAK, I., ŠTYRIAKOVÁ, I., HORÁK, D.: Isolation of polymerase chain reaction-ready bacterial DNA from Lake Baikal sediments by caroxyl-functionalised magnetic polymer microspheres, J. Chromatogr. A, 1130, 2006, 115 - 121.

ŠTYRIAKOVÁ, I., ŠTYRIAK, I.: Heterotrófne baktérie v aplikovanej mineralógii a v biotechnológiach spracovania nerudných surovín, Mineralia Slovaca, 34, 2002, 99-104.

ŠTYRIAKOVÁ, I., ŠTYRIAK, I., KRAUS, I., HRADIL, D., GRYGAR, T., BEZDIČKA, P.: Biodestruction and deferritization of quartz sands by Bacillus species. Miner. Eng., 16, 2003a, 709-713.

ŠTYRIAKOVÁ, I., ŠTYRIAK, I., GALKO, I., HRADIL, D., BEZDIČKA, P.: The release of iron-bearing minerals and dissolution of feldspars by heterotrophic bacteria of Bacillus species. Ceramics-Silikáty, 47, 2003b, 20-26.

ŠTYRIAKOVÁ, I., ŠTYRIAK, I., NANDAKUMAR, M.P., MATTIASSON, B.: Bacterial destructon of mica during bioleaching of kaolin and quartz sands by Bacillus cereus. World J. Microbiol. Biotechnol., 19, 2003c, 583 - 590.

ŠTYRIAKOVÁ, I., BHATTI, T.M., BIGHAM, J.M., ŠTYRIAK, I., VUORINEN, A., TUOVINEN, O.H.: Weathering of phlogopite by Bacillus cereus and Acidithiobacillus ferrooxidans. Can. J. Microbiol., 50, 2004, 213-219.

ŠTYRIAKOVÁ, I., ŠTYRIAK, I., MALACHOVSKÝ, P., LOVÁS, M.: Biological, chemical and electromagnetic treatment of three types of feldspar raw materials. Miner. Eng., 19, 2006, 348-354.

ŠTYRIAKOVÁ, I., ŠTYRIAK, I., MALACHOVSKÝ, P., VEČERA， Z., KOLOUŠEK, D.: Bacterial clay release and iron dissolution during the quality improvement of quartz sands. Hydrometallurgy, 89, 2007a, 99-106.

ŠTYRIAKOVÁ, I., ŠTYRIAK, I., MALACHOVSKÝ, P.: Nutrients enhancing the bacterial iron dissolution in the processing of feldspar raw materials. CeramicsSilikáty, 2007b (in press). 